\title{
Magnitude of Corporate Social Responsibility towards Firms Profitability of Indian Banks
}

\author{
Dr. Manoj Kumara N V \\ Associate Professor\& Research Guide, Department of Management Sciences, Maharaja Institute of Technology-Mysore, \\ India \\ *Correspondence: manojkumara_mba@mitmysore.in
}

\begin{abstract}
Corporate social responsibility (CSR) is terms to be self-regulating business model that, contributes firms to be socially accountable and profitable to it. The confined to selected listed Indian banks with focus concerned to be corporate initiation, motives and outcomes of such efforts related to CSR. The Study contributes towards ascertaining researcher knowledge on CSR impact on firm profitability. The present study is confined to a sample of 10 banks actively performing NSE of India. The financial variables like ROE, ROA, and EPS considered analyzing financial performance of selected companies. The stated hypotheses are proven with usage of t-test and ANOVA to ascertain the significant relationship towards CSR and Profitability. The study helps to found that there no significant change in profitability of banks and CSR activities.
\end{abstract}

Keywords: CSR, Profitability, ROE, ROA, EPS

\section{Introduction}

Corporate Social Responsibility (CSR) is a self-regulating business model that mainly focuses on procedures of interaction by an organization with its stakeholders and the public at widely by creating a motto of being responsible socially. Banking financial service and insurance (BFSI) segments is the primary driver of a nation's economy. Socially responsible is a strategy that creates a brand that image may create popularity of any business by way of recognition by public. India is the first country in the world to improve statutory obligation of CSR for corporate with specified policies. In India total INR 71,277 Crore have been spend on 1,05,358 CSR projects till 2019-20. 1

${ }^{[1]}$ https://www.investopedia.com/terms/c/corp-socialresponsibility.asp

\section{Background of the Study}

CSR and profitability are two flows in every business it is also a part of banks also. Indian banking sectors are most important sectors in Indian economy. CSR is a tool to measure business when they stay socially accountable. It is considered as a corner stone of the identity of many brands, helping shape a positive reputation. That positive reputation creates a value to any business even it is also applied to banking sector. CSR activities may impact negatively or positively towards firm's profitability it also focuses on how strategically the firm spend amount to CSR projects. Some of the bank made some contribution in Covid-19 pandemic those are Kotak Mahindra
Bank it pledge INR 60 crores (Rs 25 crores to PM Cares, Rs 10 Crores to Maharashtra CM relief fund), HDFC bank committed to Rs 150 crores to PM Cares, ICICI pledged to Rs. 80 Crores to PM Cares and Committed Rs 20 crores to state government, hospitals, CISF \& Police force provide 2.13 lakh surgical masks, 40,000 N95 masks, 20,000 liters of sanitizers, 16,000 gloves etc. they conducted CSR activities.

\section{Problem Statement}

The globalize world integration of CSR in business is one of the great challenges faced by the firm today. Stakeholders require much more from the firm other than pursuing growth and profitability. Firm which aims to be or are leaders in CSR are challenged by increasing innovation, rising public expectations, heightened social and environmental problems and continuous quality improvement. CSR activity is a dynamic and complex environment. CSR spending for that what are the factors influence CSR like firm size, firm age etc. Another problem is that CSR spending really impact the firm's profitability if yes what extent or if not, what are the reasons these are the problem statements related to this study.

Source: www.downtoearth.in

Chart 1.1 Industry wise Covid-19 response (Funds Committed)

Above charts show the industry wise Covid-19 response those are funds committed. There are 7 industry each have different way of response. The fund committed percentage are $34 \%$,

[Received 11 Oct 2021; Accepted 23 Dec 2021; Published (online) 31 Dec 2021]

Publisher's Note: RCLSS stays neutral regard to jurisdictional claims published maps (c) (1) 
$20 \%, 14 \%, 12 \%, 3 \%, 3 \%, 2 \%$ and $12 \%$ of individual sectors respectively. Those are diversified, oil drilling, BFSI, metals\& mining, auto, construction, computer software respectively. The study reports highest contribution made by diversified industry.

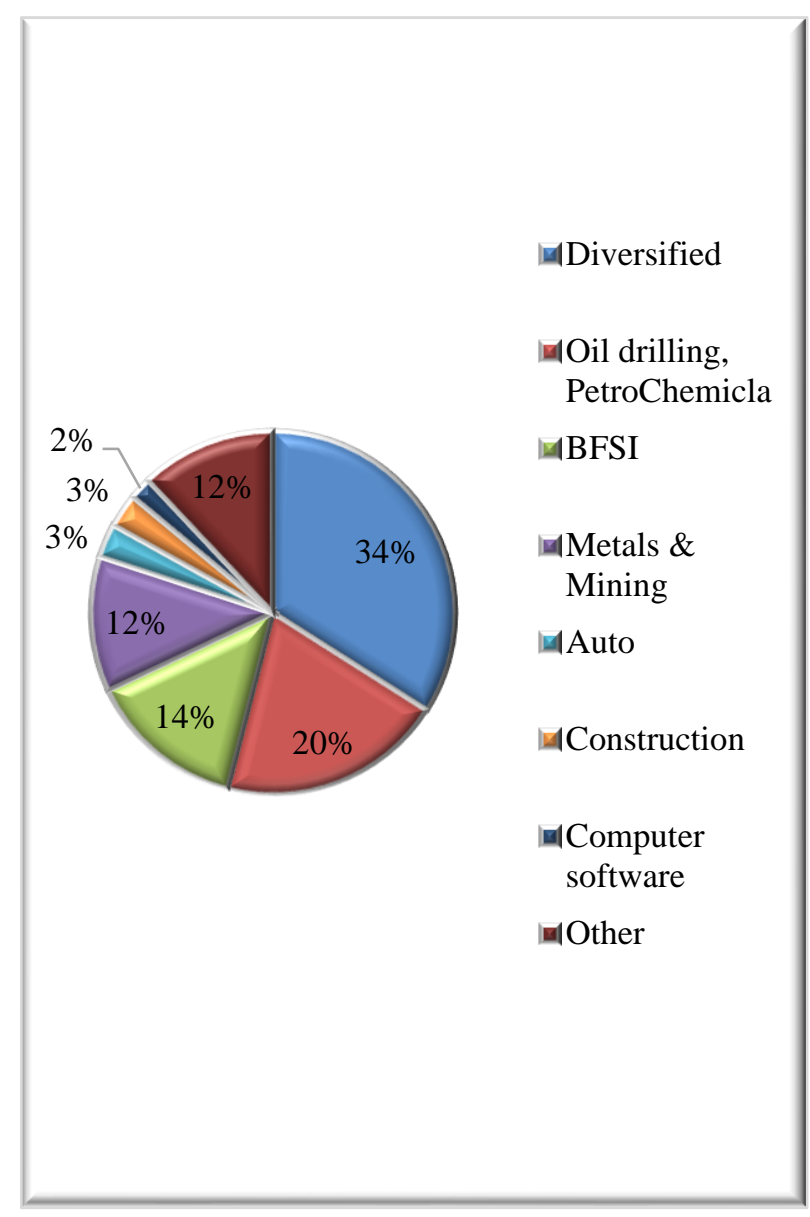

Chart 1.2 shows CSR spent by HDFC and ICICI banks high actual CSR spent in 2019-2020 Rs. 390 crores by HDFC and Rs. 170 crores by ICICI banks. Lowest spent on the year 2015-16 that is Rs. 130 crores and Rs. 180 crores by HDFC and ICICI bank respectively.

Source: www.thecsrjournal.in

Chart 1.2 HDFC and ICICI Bank Prescribed \& Actual CSR Spent (in INR Cr.)

\section{Literature Review}

Rajul Dutt ${ }^{[22]}$ (2018) study reveals that being the largest public sector bank in India the SBI investing on CSR activities this not related to profitability means can earn public views but there is negative or positive impact on profit. $\mathrm{Md}$ Habib UZ Zaman Khan ${ }^{[17]}$ (2010) CSR activity create a value to banks of Bangladesh. Som Sekhar Bhattacharyya ${ }^{[28]}$ (2008) study reveals that strategic CSR plan create a strategic gain to firm financially and non-financially. Dr Lynette M MC Donald $^{[6]}$ (2008) study finds that how much customer satisfied that many firms share price and profits grow. Labrini Sideri ${ }^{14}$ (2021) Sustainability growth of banking sectors is not fully depending on CSR activity. Dr Namita Rajput ${ }^{[7]}$ (2013) study found that net income and profitability is significant but no significant in profitability and green banking activities. Rupal Tyagi $^{\text {[24] }}$ (2013) found negative relationship between the CSP and CFP. Mobin Fatma ${ }^{19}$ (2016) CSR activities draw the public by increasing purchase and build image of retail banking. Ali Raza ${ }^{[3]}$ (2020) CSR is not directly linked with customer loyalty. Leena James ${ }^{15}$ (2012) CSR may a part of increase profitability of companies. Shachi Rai ${ }^{[26]}$ (2015) CSR activity it is depends on company profitability. Manisha Sayena $^{[16]}$ (2012) reports that insignificant impact of CSR on profitability. Merve Kilic ${ }^{[18]}$ (2015), CSR depends on size, ownership and broad of the banks CSR disclosure. Robert D Klassen $^{[23]}$ (1996), environmental management and financial performance create impact on firm.

Atang Hermawan ${ }^{[5]}$ (2019) CSR activity influence by various factors like size, profitability, leverage, ownership etc by this conclude that there is no relation with them. SandhikaCipta Bidhari ${ }^{[25]}$ (2013)CSR impact on all financial performance ROE, ROA, ROS but ROS didn't effect on firm value. Shangzhi Charles Qiu ${ }^{[27]}$ (2021) CSR activity protects financial value during Covid-19 pandemic. KshitizUpadhyay Dhungel $^{[13]}$ (2011) CSR help to improve societal responsibility. Suman Kalyan Chaudhury ${ }^{[29]}$ (2011) found that CSR activity impact on banking performance. Jignesh $\mathrm{J}$ Patel $^{[12]}$ (2015) CSR activity has challenges, but it has positive support to society. Namrata $\operatorname{Singh}^{20}$ (2013) CSR practices create a value to banks. Henri Servaes ${ }^{11}$ (2013) CSR improve reputation of firm value. AbdulahadAbdulbasith (2019) proved negative impact of profitability. Om Prakash Agrawal $^{[21]}$ (2020) CSR activity helps to positive and strong impact of financial performance. Faizi Weqar ${ }^{[9]}$ (2020) effeicency of IC significantly enhances the profitability and productivity of the Indian bank. Elena Platonova ${ }^{8}$ (2018) covered CSR disclosure and the future financial performance of GCC Islamic bank. Adriana Galant ${ }^{2}$ (2017) CSR \& CFP have positive relations. Amal Abou Fayad ${ }^{4}$ (2017) adopt volunteer actions that promote social responsibility actions. Grizel Menezes ${ }^{[10]}$ (2019) net profit has a significant relationship with the CSR spending where as ROA and EPS have no impact. Suvendu Kr Pratihari ${ }^{[30]}$ (2018) relation between CSI disclosures and profitability is significant. 


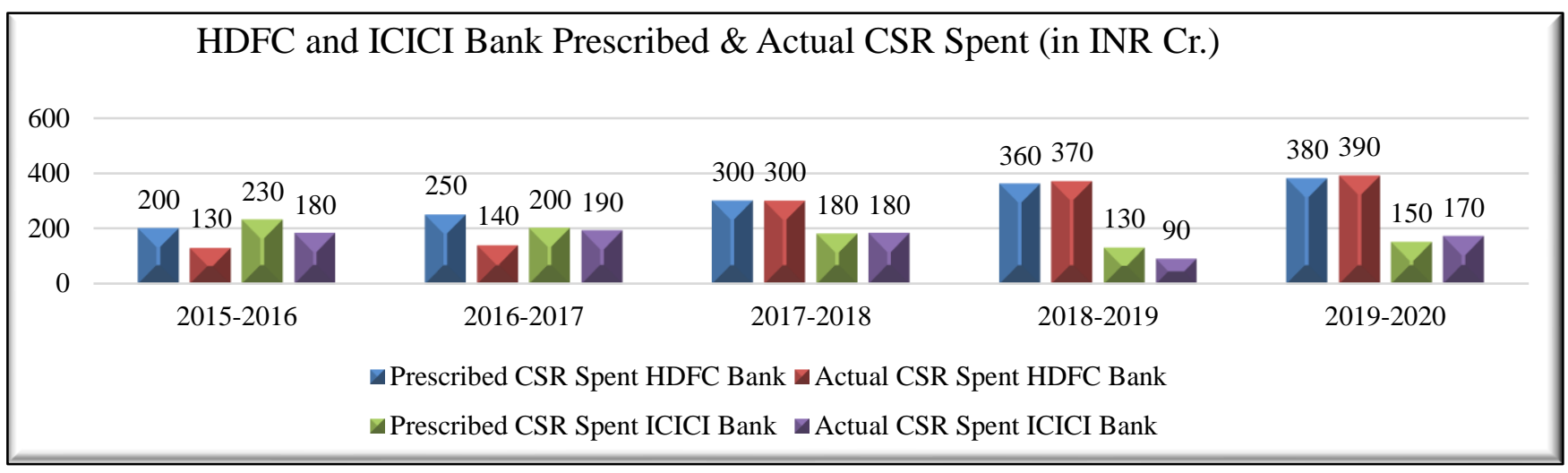

The above results clearly show that there is both positive and negative impact for the business. So the present study mainly focus on Magnitude of Corporate Social Responsibility towards Firms Profitability of Indian Banks

\section{Objectives of the Study}

$>$ To analyze significant impact CSR on financial performance of selected banks.

$>$ To examine significant impact of profit variable and CSR contribution.

\section{Research Methodology}

The following Table -1 represents the research methodology inculcated in this research paper

Table 1 Research Design

Research Study

Research Method

Sample Method Empirical Study

Descriptive \& Analytical Research Simple Random Sampling Method

Sampling Technique Convenient Sampling Technique Sample 10 Banks

Table 2 Selected Banks from NSE as a sample size

\begin{tabular}{l|l}
\hline Banks Name & Banks Name \\
\hline 1.HDFC Bank & 6. Bhandan Bank \\
2. ICICI Bank & 7.Yes Bank \\
3.Kotak Mahindra Bank & 8. Karnataka Bank \\
4. Axis Bank & 9.Indusland Bank \\
5. Federal Bank & 10.City Union Bank \\
\hline
\end{tabular}

\section{Description of the study area:}

\section{Source of data:}

Secondary Data: -Data were collected using banks website and moneycontrol.com

\section{Tools for the study}

Mean: Arithmetic mean is of given set of data is the sum of data divides the number of observations this is also called as simple average and is denoted by $\bar{X}$. Mean is used in the study to check the high and low mean value by the firm.

$$
\overline{\mathrm{X}}=\frac{\Sigma \mathrm{x}}{\mathrm{N}}
$$

Standard deviation: - Elements of the set are more dispersed than standard deviation becomes larger. The SD is used to find the deviation level of CSR activity and profit position of the firm. $\quad \sigma=\sqrt{\frac{\sum(\mathrm{x}-\overline{\mathrm{x}})}{\mathrm{n}-1}}$

ANOVA: -Use to find relation between independent and dependent variable related to CSR and profitability variables. T-test: -. It is used in study to test difference between means of two samples that is dependent sample or paired observation. $\quad \mathrm{t}=\frac{\overline{\mathrm{x}}-\mu}{\sqrt{\mathrm{s}^{2} / \mathrm{n}}}$

\section{Hypothesis}

$\mathrm{H}^{1}=$ There is no statistically significant impact of CSR on Net profit.

$\mathrm{H}^{2}=$ There is no statistically significant impact of CSR on ROE, ROA and EPS.

\section{Analysis and Interpretation}

The study mainly focusing on CSR impact on profitability of selected banks listed in NSE, for the analysis use statistical tools are and mean, t-test, SD, ANOVA.

Table 3

One-Sample Statistics

\begin{tabular}{llrrr}
\hline \multicolumn{1}{r}{ Ratios } & N & \multicolumn{1}{c}{ Mean } & $\begin{array}{c}\text { Std. } \\
\text { Deviation }\end{array}$ & $\begin{array}{c}\text { Std. Error } \\
\text { Mean }\end{array}$ \\
\hline CSREXP & 50 & 71.46 & 97.78 & 13.82 \\
NP & 49 & 4234.77 & 4899.83 & 699.97 \\
ROA & 50 & 1.34 & .72 & .10 \\
ROE & 50 & 11.39 & 5.72 & .80 \\
EPS & 50 & 21.58 & 20.00 & 2.82 \\
FIRMAGE & 50 & 44.80 & 36.81 & 5.20 \\
FIRMSIZE & 50 & 160702.79 & 189457.49 & 26793.33 \\
\hline \multicolumn{4}{l}{ Source: - Author's Calculation-SPSS Database }
\end{tabular}


Magnitude of Corporate Social Responsibility towards Firms Profitability of Indian Banks

\begin{tabular}{|c|c|c|c|c|c|c|c|c|}
\hline \multirow[b]{2}{*}{ Model } & \multirow[b]{2}{*}{$\mathrm{R}$} & \multirow{2}{*}{$\begin{array}{c}\mathrm{R} \\
\text { Square }\end{array}$} & \multirow{2}{*}{$\begin{array}{l}\text { Adjusted R } \\
\text { Square }\end{array}$} & \multirow{2}{*}{$\begin{array}{l}\text { Std. Error of the } \\
\text { Estimate }\end{array}$} & \multicolumn{4}{|c|}{ Change Statistics } \\
\hline & & & & & $\begin{array}{l}\text { R Square } \\
\text { Change }\end{array}$ & F Change & df2 & $\begin{array}{l}\text { Sig. F } \\
\text { Change }\end{array}$ \\
\hline 1 & 0.918 & 0.843 & 0.840 & 39.515 & 0.843 & 252.205 & 47 & 0.000 \\
\hline 2 & 0.931 & 0.866 & 0.860 & 36.889 & 0.023 & 7.931 & 46 & 0.007 \\
\hline 3 & 0.931 & 0.867 & 0.858 & 37.193 & 0.001 & 0.250 & 45 & 0.619 \\
\hline 4 & 0.931 & 0.867 & 0.855 & 37.610 & 0.000 & 0.010 & 44 & 0.923 \\
\hline
\end{tabular}

The above table 3 shows that one-sample statistics by this analyze that highest mean value is firm size that is 160702.79 and NP is 4234.77 and lowest mean value 1.34 in ROA. High deviation in in firm size 189457.49 and NP is 4899.83 . The low deviation in ROA is 0.72 . CSR expenditure is mean value is 71.46 and deviation is 97.78 . Firms size, age and CSR expenditure are the variable is related with NP, ROA, ROE, and EPS.

Table $4 \quad$ One-Sample Test

Source: - Author's Calculation-SPSS Database

\begin{tabular}{lrrrcc}
\hline \multicolumn{1}{c}{ Model } & $\begin{array}{c}\text { Sum of } \\
\text { Squares }\end{array}$ & df & $\begin{array}{c}\text { Mean } \\
\text { Square }\end{array}$ & F & Sig. \\
\hline Regression & 393811.32 & 1 & 393811.32 & 252.205 & 0.000 \\
Residual & 73389.17 & 47 & 1561.47 & & \\
Total & 467200.49 & 48 & & & \\
Regression & 404603.53 & 2 & 202301.77 & 148.663 & 0.000 \\
Residual & 62596.96 & 46 & 1360.80 & & \\
Total & 467200.49 & 48 & & & \\
Regression & 404949.58 & 3 & 134983.19 & 97.577 & 0.000 \\
Residual & 62250.91 & 45 & 1383.35 & & \\
Total & 467200.49 & 48 & & & \\
Regression & 404963.05 & 4 & 101240.76 & 71.574 & 0.000 \\
Residual & 62237.44 & 44 & 1414.49 & & \\
Total & 467200.49 & 48 & & & \\
\hline
\end{tabular}

Table $6 \quad$ Model Summary

Source: - Author's Calculation-SPSS Database

Table 6 shows the independent and dependent variable relations those are ROE, ROA, NP, EPS, Firm Size, Firm Age with CSREXP. ROA, ROE, NP, EPS are constant. Significant $\mathrm{F}$ change is $0.000,0.007,0.619,0.923$.

Table 7 ANOVA

Source: - Author's Calculation-SPSS Database

\begin{tabular}{lrrrr} 
Ratios & \multicolumn{1}{c}{ t } & df & Sig. (2-tailed) & $\begin{array}{c}\text { Mean } \\
\text { Difference }\end{array}$ \\
\hline CSREXP & 5.167 & 49 & .000 & 71.46 \\
NP & 6.050 & 48 & .000 & 4234.77 \\
ROA & 13.143 & 49 & .000 & 1.34 \\
ROE & 14.082 & 49 & .000 & 11.39 \\
EPS & 7.627 & 49 & .000 & 21.58 \\
FIRMAGE & 8.606 & 49 & .000 & 44.80 \\
FIRMSIZE & 5.998 & 49 & .000 & 160702.79 \\
\hline
\end{tabular}

Table 7 shows that there is no significant change in CSR and Profit variable during study period. There is no significant relationship between CSR Spending and Profit Variables (NP, ROA, and ROE \& EPS). There is no

Above table 4 shows find the significant level of all variables those are CSREXP, NP, ROA, ROE, EPS, Firm AGE, Firm Size. All variable has significant that is 0.000 . Highest t-test value is ROE 14.082 and lowest is 5.167 that is CSREXP. significant impact of CSR Spending on Profit Variables. Significant level is 0.000 . High change value is 252.205 and lowest change value is 71.574

\begin{tabular}{lrrrrrr} 
Table 5 & \multicolumn{7}{c}{ Correlations } \\
\hline Particulars & & EXP & NP & ROA & ROE & EPS \\
\hline Pearson & CSR & & & & & \\
$\begin{array}{l}\text { Correlation } \\
\text { Sig. (1- }\end{array}$ & EXP & 1 & 0.918 & 0.042 & 0.173 & 0.507 \\
tailed) & CSR & & & & & \\
& EXP &. & 0.000 & 0.389 & 0.117 & 0.000 \\
& $\mathrm{~N}$ & 49 & 49 & 49 & 49 & 49 \\
\hline
\end{tabular}

Source: - Author's Calculation-SPSS Database

Above Table 5 shows the correlations between CSREXP with NP, ROA, ROE and EPS. CSREXP have positive correlation between NP, ROA, ROE and EPS that is 0.91811, 0.0415, 017306, 0.50679. The study found that positive significant levels in CSREXP with NP and EPS that is 0.000 .

\section{Results and Discussion}

- There is no significant relationship between CSR Spending and Profit Variables (NP, ROA, and ROE \& EPS). There is no significant impact of CSR Spending on Profit Variables. Significant level is 0.000 . High change value is 252.205 and lowest change value is 71.574

- The independent and dependent variable relations those are ROE, ROA, NP, EPS, Firm Size, Firm Age with CSREXP. ROA, ROE, NP, EPS are constant. Significant F change is $0.000,0.007,0.619,0.923$.

- The significant level of all variables those are CSREXP, NP, ROA, ROE, EPS, Firm AGE, Firm Size. All variable has significant that is 0.000 . Highest $t$-test value is ROE 14.082 and lowest is 5.167 that is CSREXP. 
- Highest mean value is firm size that is 160702.79 and NP is 4234.77 and lowest mean value 1.34 in ROA. High deviation in in firm size 189457.49 and NP is 4899.83. The low deviation in ROA is 0.72 . CSR expenditure is mean value is 71.46 and deviation is 97.78 . Firm's size, age and CSR expenditure are the variable is related with NP, ROA, ROE, and EPS.

\section{Conclusion}

The study mainly related to know relationship of CSR spending and profit variables of listed banks in NSE in India. For the study use the sample of 10 listed banks in NSE. The study confined the dependent and independent variables like firm size, firm age, ROE, ROA, EPS, NP and CSR expenditure. CSR programs have generally been most common among large corporations; small businesses also participate in CSR through smaller-scale programs such as donating to local charities and sponsoring local events.

Conflicts of Interest: The authors declare no conflict of interest.

Acknowledgments: I acknowledge the support of colleagues\& Dear Students of the Maharaja Institute of Technology Mysore, for their grateful comments and insights in improving the paper.

\section{References}

[1]. Abduladha Abdulbasith, (2019), "Environmental, Social \& Governance Disclosure and Profitability: GCC Bank's Comparative Study", pp.1-45.

[2]. Adriana Galant, Simon Cadez, (2017), "Corporate Social Responsibility and Financial Performance Relationship: A review of measurement approaches", Economic Research, ISSN-1331667X, Vol.30, No.1, pp.676-693.

[3]. Ali Raza, Raouf Ahmad Rathr, (2020), "An assessment of corporate social responsibility on customer company identification and loyalty in banking industry a PLS-SEM analysis", Management Research Review, ISSN-2020-8269, pp.1-34.

[4]. Amal Abou Fayad, Razan Ayoub, (2017), "Causal relationship between CSR and FB in banks", Vol.12, pp.93-98.

[5]. Atang Hermawan, Ardi Gunardi, (2019), "Motivation for disclosure of corporate social responsibility: Evidence from banking industry in Indonesia", Entrepreneurship and Sustainability Issues, Vol.6, No.3, pp.1297-1306.

[6]. Dr Lynette M McDonald, Sharyn Rundle Thiele, (2008), "Corporate social responsibility and bank customer satisfaction: A research agenda",
International Journal of Bank Marketing, ISSN0265-2323Vol. 26, No.3, pp.170-182.

[7]. Dr Namita Rajput, Simple Arora, Akanksha Khanna, (2013), "An empirical study of impact of environmental performance on financial performance in Indian banking sector", IJBMI, ISSN-2319-801X, Vol. 2, No.9, pp.19-24.

[8]. Elena Platonova, Mehmet Asutay, Rob Dixou, (2018), "The impact of Corporate Social Responsibility disclosure on financial performance: Evidence from the GCC Islamic Banking Sector", Springe, pp.451-471.

[9]. Faizi Weqar, Ahmed Mura Khan, (2020), "Exploring the effect of intellectual capital on financial performance: A study on Indian banks", ISSN-1368-3047,pp-1-19.

[10]. Grizel Menezes, (2019), "Impact of CSR spending on firm's financial performance", IJARIIT, Vol.5, No.2, pp.613-617.

[11]. Henri Servaes, Ane Tamayo, (2013), "The impact of Corporate Social Responsibility on firm value: The role of customer awarence", Management Science, ISSN-0025-1909,Vol.59, No.5, pp.1045-1061.

[12]. Jignesh J Patel, (2015), “Corporate Social Responsibility: Challenges in India”, RHIMRJ, Vol.6, No. 37, pp.1-6.

[13]. Kshitiz Upadhyay Dhungel, Anar Dhungel, (2011), "Corporate Social Responsibility reporting practices in the banking sector of Nepal", Banking Journal, Vol.3, No.1, pp.1-36.

[14]. Labrini Sideri, (2021), "Leveraging CSR for sustainability: Assessing performance implications of sustainability reporting in a national business system", MDPI, Vol.13, pp.1-16.

[15]. Leena James, (2012), "Prospects of CSR: An overview of 500 Indian companies", The IUP Journal of Corporate Governance, Vol.11, No.4, pp.1-17.

[16]. Manisha Sayena, (2012), "Impact of corporate social responsibility on corporate suitability: A study of the Indian banking industry", The IUP General of Corporate Governace, Vol.11, No.4, pp.1-31.

[17]. Md Habib UZ Zaman Khan, (2010), "The effect of corporate governance elements on corporate social responsibility (CSR) reporting empirical evidence from private commercial banks of Bangladesh", IJLMA, Vol.52, No.2, pp.82-109.

[18]. MerveKilic, Cemil, Kuzey, Ali Uyar, (2015), "The impact of ownership and board structure on corporate social responsibility (CSR) reporting in the Turkish banking industry" ISSN-1472-0701, Vol.15, No.3, pp.357-374.

[19]. MobinFatma, Zillur Rahman,(2016), "The CRS's influence on customer responses in Indian banking 
sector", Journal of Retailing and Consumer Services, Vol.29, pp.49-57.

[20]. Namrata Singh, Rajlaxmi Srivastava, (2013), “CSR Practice \& CSR Reporting in Indian Banking Sector", International Journal of Scientific and Research Publications, ISSN-2250-3153,Vol.3, No.12, pp.1-8.

[21]. Om Prakash Agrawal, Prateek Kumar, (2020), "Effect of financial performance on corporate social responsibility and stock price: A study of BSE listed companies", International Journal on Emerging Technologies, ISSN-0975-8364, Vol.11, No.1, pp.286-291.

[22]. RajalDutt, Himani Grewal, (2018), "Corporate Social Responsibility (CSR) in Indian Banking Sector: An Empirical study on State Bank of India Limited", Amity Journal of Corporate Governance, Vol.3, No.1, pp.33-43.

[23]. Robert D Klassen, Currtis P Mclaughlin, (1996), "The impact of environmental management on firm performance" Management Science, Vol.42, No.8, pp. 1199-1214.

[24]. RupalTyagi, Anil K Sharma, (2013), "Corporate social performance and corporate financial performance: A link for the Indian firms", Issuesin Social and Environmental Accounting, ISSN-19780591, Vol.7, No.1, pp.4-29.

[25]. SandhikaCiptaBidhari, Ubudsalim, SitiAisjah, (2013), "Effect of corporate social responsibility information disclosure on financial performance and firm value in bankingindustry listed at Indonesia stock exchange", European Journal of Business and Management, ISSN-2222-1905, Vol.5, No.18, pp.39-47.

[26]. Shachi Rai, Sanfeeta Bansal, (2015), "Factors explaining corporate social responsibility expenditure in India", Review of Market Integration, Vol.7, No.1, pp.1-25.

[27]. ShangzhiReza Charles Qiu, Jianing Jiang, (2021), "Can Corporate Social Responsibility protect firm value during the Covid-19 Pandemic?", pp.1-12.

[28]. SomSekhar Bhattacharyya, Arunditya Sahay, Ashok Pratap Arora, AbhaChaturvedi, (2008), "A tool kit for designing firm level strategic corporate social responsibility (CSR) Initiative", Social Responsibility Journal, Vol. 4, No.3, pp.265-212.

[29]. Suman KalyanChaudhury, Sanjay Kanti DAS, (2011), "Practice of Corporate Social Responsibility (CSR) in banking sector in India: An assessment", Research Journal of Economic, Business and ACT, ISSN-2045-3345, Vol.4, pp.76-81.

[30]. Suvendu Kr Pratihari, Shigufta Hena Uzma, (2018), "Corporate Social Identify: An analysis of the Indian banking sector", International Journal of Bank Marketing, ISSN- 0265-2323, pp.1248-1284. 